\title{
Contamination by particulated material in blasts: analysis, application and adaptation of the existent calculation formulas and software
}

\author{
J. Toraño, R. Rodríguez, I. Diego \& A. Pelegry \\ Mining and Mine Prospecting Department, University of Oviedo
}

\begin{abstract}
In the setting of a research project about the blasting negative effects granted with public funds coming from the Spanish Ministry for Development, several measurement campaigns were developed, in various locations and situations, where earth vibrations, aerial waves and dust in suspension simultaneously measured. Taking into account the dust negative effects (for human health, inhabited environment or plants) it is interesting to have available tools that allow the estimation of the particulated material quantities ejected in a blast (already studied by our research team in other cases). Here we show the application of the standardised computational methods for atmospheric contamination (developed for other applications) in the specific case of blasting in mining and civil works. To do so we have used the field data collected in blasts at a maritime port and at a limestone quarry. We will also show the advantages of using CFD when solving some of these problems, which is being studied in other research projects.
\end{abstract}

Keywords: particulated material, blast, atmospheric contamination, dust.

\section{Dust generation in a blast}

One of the main particle sources of the atmospheric contamination are the industrial activities. From their size and nature we can infer the affections that dust can induce in human beings. According to dust size we can categorize it in three groups: breathable dust (particles so small that go directly to lungs), inhaled dust (one part is retained by the upper part of the human breathing system, whit diameters around $10 \mu \mathrm{m}$ ) and total dust. Up to recent dates it was thought that the harmful action of those particles in people was limited to 
breathing system (National Institute for Silicosis Disease [4]) with the result of a first classification according to human beings affections: pneumoconiotic dust, toxic dust, inert dust and allergic dust.

Studies done "ad hoc" proof that during the last years there are more evidences of carcinogenic effects of dust containing free silica (International Agency for Cancer Research [5]) and the contribution of those particles to the cardiovascular pathologies (Ballester [6]). We must point out that the diseases produced by these contaminations have a special importance on children (World Health Organization Reports [7]). Blasting, or rock explosions, involves a high level of contamination by particulated material. This dust sources are intermittent, frequent, sporadic and very short in time. A cloud is produced, formed by the pulverized rock, the perforation debris and the projection of the dust previously settled in the blasting area.

\section{Measurement campaigns to characterize the dust produced in a blast}

The 4 measurement campaigns selected for this study were done in "El Musel" maritime port (blasts in concrete structures) and in "El Perejil" limestone quarry, both in Asturias, northern Spain. During the measurement campaigns we used dust collectors Met One $(<50 \mu)$, which allow continuous measurement of PM2.5, PM-10, total particles, atmospheric pressure and temperature, as well as meteorological stations (sensors E-sampler EX034 and HR-E Sampler EX593) in order to measure continuously air humidity and wind speed and direction.

\subsection{Blasts in a maritime port}

First blasts were done in 10th of April, 2004 at the dock of "La Osa" wharf (Figures 1 and 2), where a 100 meters long concrete dock wall was being demolished. The blasting characteristics are shown in Table 1. Meteorological conditions during the test were: temperature of $8^{\circ} \mathrm{C}, 1022$ millibar atmospheric pressure, clouds, no rain, wind speed ranging $1-2 \mathrm{~m} / \mathrm{s}$ and $40-60^{\circ}$ of bearing in relation to the concrete wall, very small sunshine ratio (due to clouds) and relative humidity between $60-80 \%$. We can say also that the ground was wet due to past days rain and the area was a suburban zone with wind flow obstacles in the back side of the dock and completely free from obstacles in the wind upcoming area.

Table 1: $\quad$ Blasting characteristics.

\begin{tabular}{|c|c|}
\hline Height, Burden and shots spacing $(\mathrm{m})$ & $3.80,1.3$ and 1.2 \\
\hline Length, diameter, slope, clay stopper & $4 \mathrm{~m}, 54 \mathrm{~mm}, 5\left(^{\circ}\right)$ and $2.4 \mathrm{~m}$ \\
\hline Main and Bottom Load & $0.87 \mathrm{~kg}$ and $0.46 \mathrm{~kg}$, dynamite \\
\hline Number of shots and type of firing & 80, non electric detonators \\
\hline
\end{tabular}




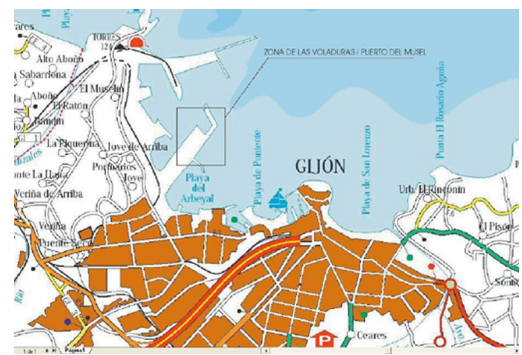

Figure 1: Port location.

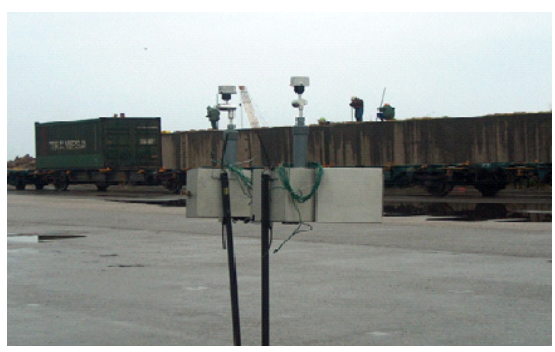

Figure 2: Dock wall and installed dust collectors.

In a first step the dust sensors were installed together 40 meters apart from the blast, one measuring PM-2.5 and another one PM-10; in a second step we brought one of the sensors close to the blast (12 $\mathrm{m}$ from it), measuring both of them total particles before and after the blast. Before the blast the PM-10 dust concentration ranged from 0.02 to $0.025 \mathrm{mg} / \mathrm{m}^{3}$; PM- 2.5 ranged again from 0.02 to $0.025 \mathrm{mg} / \mathrm{m}^{3}$. Figures 3 and 4 show the concentration increase of total particles. Calculations done from the samples give values of: $40 \mathrm{~m}$ apart from the dock $(\mathrm{C})=0.220 \mathrm{mg} / \mathrm{m}^{3}$ and $12 \mathrm{~m}$ from the dock $(C)=0.359 \mathrm{mg} / \mathrm{m} 3$. In 2 minutes, approximately, the particle concentration measurement gets stabilized again, as the dust cloud has already been displaced by the wind.

On 19th April, 2004 other two dock concrete pieces were blasted, as is shown in Figure 5. Meteorological conditions were: temperature of $11^{\circ} \mathrm{C}, 1007$ millibar atmospheric pressure, clouds, no rain, wind speed ranging $4-5 \mathrm{~m} / \mathrm{s}$ and $5-15^{\circ}$ of bearing in relation to the concrete wall, very small sunshine ratio (due to clouds) and relative humidity between $60-80 \%$. Again the ground was wet due to previous the day's rain and there were no obstacles to wind in the area. 2 dust collectors were installed $25 \mathrm{~m}$ and $50 \mathrm{~m}$ respectively apart and perpendicular to the dock. Table 2 and Table 3 show the blasts main characteristics. The sensor measured the particle concentration increase due to the 2 blasts in the same way as the previous blast. Dust concentration produced by blast in the points where the sensors were installed were: $25 \mathrm{~m}$ from the dock $(\mathrm{C})=1.069 \mathrm{mg} / \mathrm{m}^{3}$, and 50 $\mathrm{m}$ from the dock $(\mathrm{C})=0.829 \mathrm{mg} / \mathrm{m}^{3}$.

\subsection{Blasts in a limestone quarry}

The quarry is located in the core of the downfold geological structure and produces limestone (Figure 7). The meteorological conditions in the first measured blasts, 13th May 2004, were: temperature of $18^{\circ} \mathrm{C}, 1022.5$ millibar atmospheric pressure, sunny day with no clouds, no rain, wind speed ranging 1-2 $\mathrm{m} / \mathrm{s}$ and $90^{\circ}$ of bearing in relation to the trench face, high sunshine ratio and relative humidity between $50-60 \%$, upper part of bench wet. Country area. Blast characteristics are shown in Table 4 and Figure 8. 


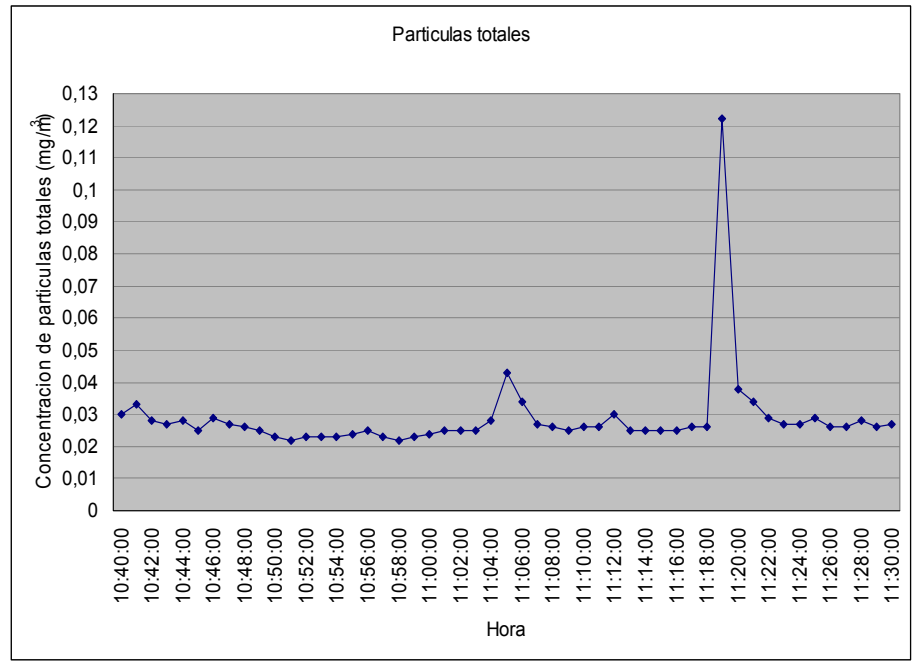

Figure 3: Total particle sample @ 40m collector.

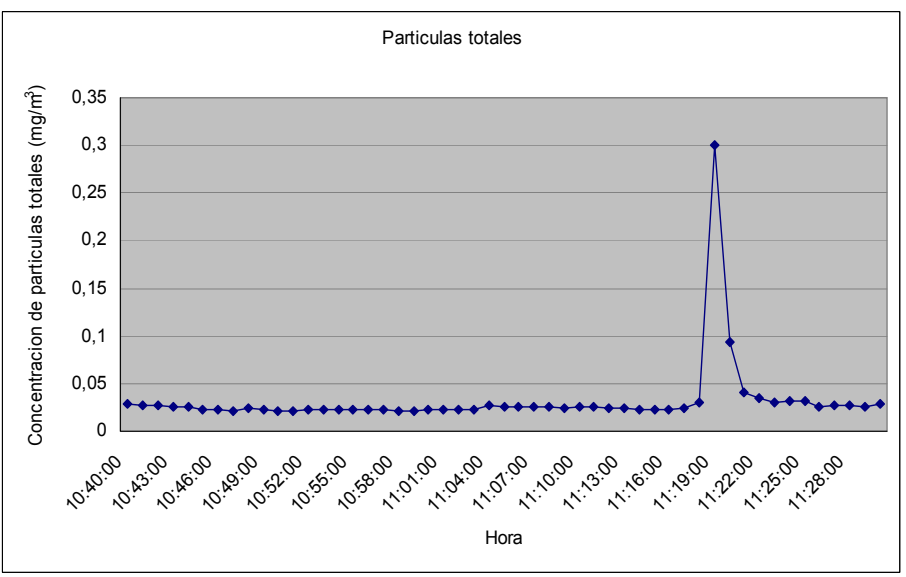

Figure 4: Total particle sample @12m collector.

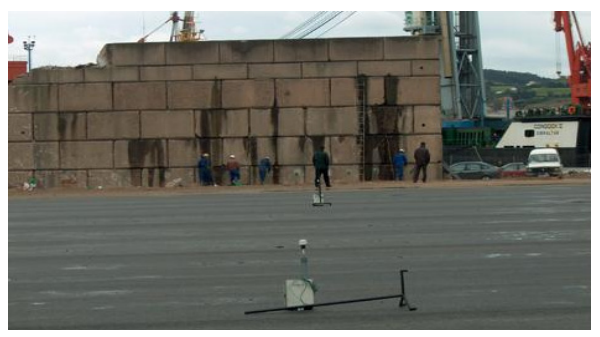

Figure 5: Initial time.

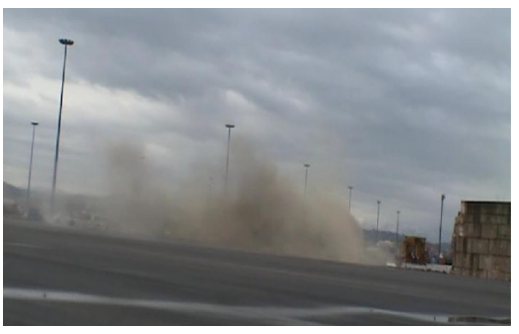

Figure 6: Dust dispersion. 
Table 2: $\quad$ Blast characteristics - First section of dock

\begin{tabular}{|c|c|}
\hline Height, Burden and shots spacing $(\mathrm{m})$ & $3,1,4$ and 1,2 \\
\hline Length, diameter, slope, clay stopper & $54 \mathrm{~mm}$, vertical and $2,4 \mathrm{~m}$ \\
\hline Main and Bottom Load & $1,45 \mathrm{~kg}$ and $0.69 \mathrm{~kg}$ \\
\hline Number of shots and type of firing & 64 non electric detonators \\
\hline
\end{tabular}

Table 3: $\quad$ Blast characteristics - Second section of dock

\begin{tabular}{|c|c|}
\hline Height, Burden and shots spacing $(\mathrm{m})$ & $4.5,1.4$ and 1.2 \\
\hline Length, diameter, slope, clay stopper & $54 \mathrm{~mm}$, vertical + horizontal, $2.4 \mathrm{~m}$ \\
\hline Main and Bottom Load & $1.74 \mathrm{~kg}, 0.69 \mathrm{~kg}$ and $1.71 \mathrm{~kg}$ \\
\hline Number of shots and type of firing & 44, non electric detonators \\
\hline
\end{tabular}

Two dust collector were installed 125 meters apart from the bench in the covering area, measuring PM-2.5 and PM-10 before blasting; further on total particles were measured before and after the blasting (Figures 9 and 10).

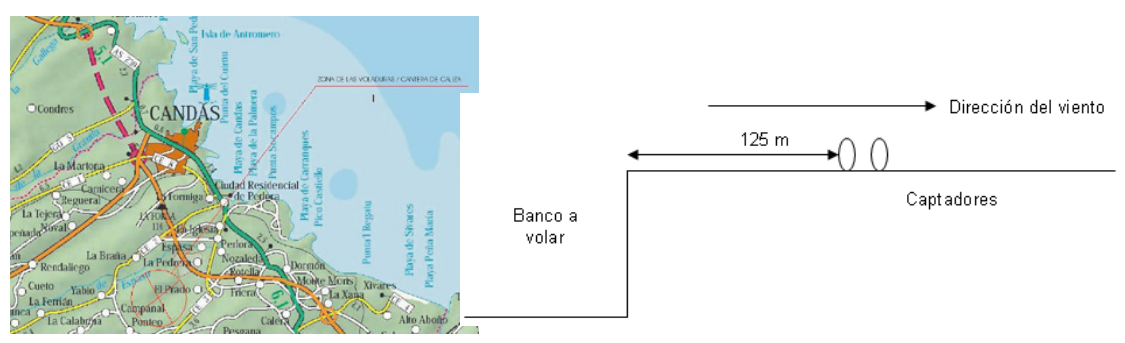

Figure 7: "El Perecil” quarry map.

Figure 8: Sensors location.

Table 4: $\quad$ Characteristics of the bench blasting (UEE explosives).

\begin{tabular}{|c|c|}
\hline Height, Burden and shot spacing $(\mathrm{m})$ & 18,4 and 5 \\
\hline Length, diameter, slope, clay stopper & $120 \mathrm{~mm}, 15^{\circ}$, horizontal, 3 m \\
\hline Total Load (dynamite), Nr of shots & $1175 \mathrm{~kg}$ and 13 \\
\hline $\begin{array}{c}\text { Bottom and Head firing, Detonating } \\
\text { cord type and firing }\end{array}$ & $\begin{array}{c}\text { EZDET }(25 / 350 \mathrm{~ms}) \text { and } \mathrm{Ms} \mathrm{N} \mathrm{N}^{\circ} 16 \\
(450 \mathrm{~ms})\end{array}$ \\
\hline Firing and detonating cord & Electrical Nr 0 and EZTL (17ms);20m \\
\hline
\end{tabular}

The particle PM-2.5 concentration ranged between 0.03 and $0.05 \mathrm{mg} / \mathrm{m}^{3}$ and PM-10 concentration ranged between 0.035 and $0.06 \mathrm{mg} / \mathrm{m}^{3}$. Total particle concentration alter the blast were similar, with values of $0.156 \mathrm{mg} / \mathrm{m}^{3}$ and 0.199 $\mathrm{mg} / \mathrm{m}^{3}$, which means a mean value of $0.177 \mathrm{mg} / \mathrm{m}^{3}$. Figures 11 and 12 show the dust formation and dispersion phases, as well as the position of the dust collectors. Although the blast boost down and straight the dust cloud it then 
follows the wind direction, slides over the bench face, overpass it and then were dispersed.

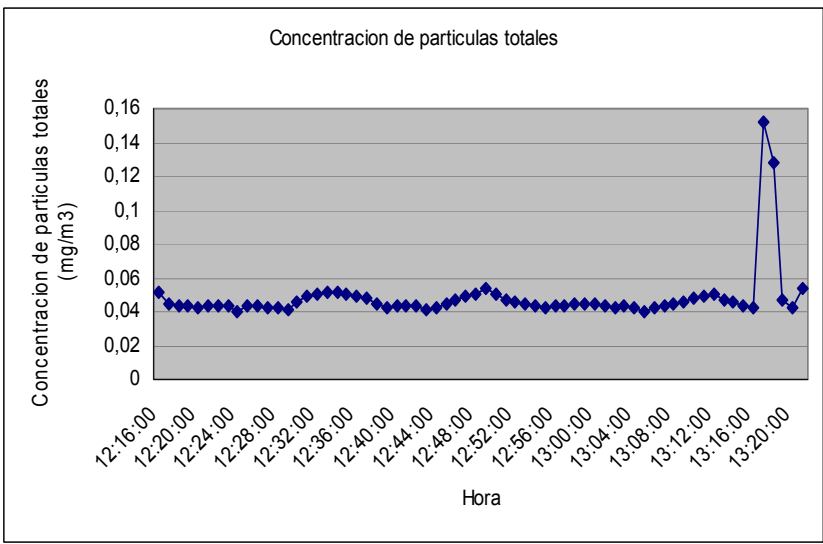

Figure 9: Total particules sample - collector 1.

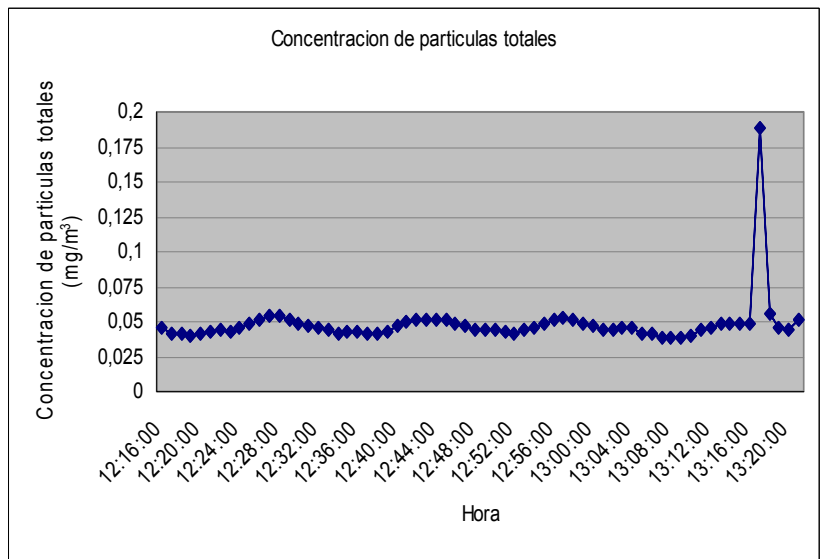

Figure 10: Total particules sample - collector 2 .

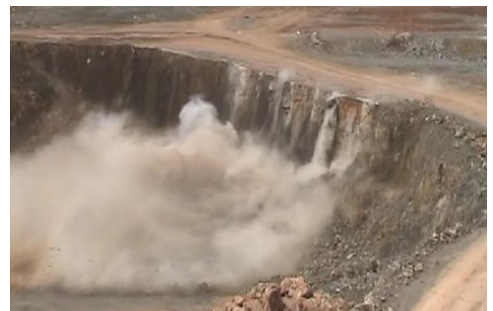

Figure 11: Dust creation.

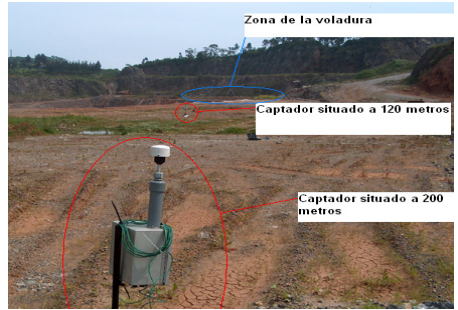

Figure 12: Samplers detail. 
21st May 2004 blasts and its main characteristics are shown in Table 5. Dust concentration produced by the blast was, where the dust collectors were installed, $0.406 \mathrm{mg} / \mathrm{m}^{3} 200 \mathrm{~m}$ apart from the bench and $0.733 \mathrm{mg} / \mathrm{m}^{3} 120 \mathrm{~m}$ apart. In the same way as in the previous cases, dust was boosted down and straight and then back following wind direction.

Table 5: $\quad$ Characteristics of the blasting (UEE explosives). 21-04-04.

\begin{tabular}{|c|c|}
\hline Height, Burden and shot spacing $(\mathrm{m})$ & $16,2,4$ and 5 \\
\hline Length, diameter, slope, clay stopper & $120 \mathrm{~mm} ; 15^{\circ}$ and horizontal; $2,83 \mathrm{~m}$ \\
\hline Total Load (dynamite) and shot $\mathrm{Nr}$ & $1300 \mathrm{~kg} ; 12$ \\
\hline Bottom and Head firing & EZDET(25/350ms);Ms Nr16 (450ms) \\
\hline Firing and detonating cord & Electrical Nr0;EZTL $(17 \mathrm{~ms}) ; 19 \mathrm{~m}$ \\
\hline
\end{tabular}

\section{Blast simulation using isc3 software}

\subsection{Maritimal port blast}

We will use ISC3 software [8] and [9] in order to simulate the blasts measured. Meteorological field data are introduced in the ISC3, obtaining Table 6 as the meteorological values output. Figure 13 shows the inferred wind rose. Dust sources are introduced defining the size of the blasted dock, its emission height and the amount of emitted pollutant. Source used will be polygonal type, as it allows us to define the irregular shape of the dock, using UTM coordinate systems in order to maintain portability with software Aermod. We will also define in the software the particle nature, its size distribution and its density, $\mathrm{s}$ well as the source coordinates and the measuring point's coordinates in order to simulate the same configuration as we had in the blast measuring campaigns.

Starting from the coordinates assigned to the source we establish two receptors types. The first is a discrete network made by 2 node receptors that simulate the position of the samplers in the field tests and that will allow us to check the modelization against the field measurements. The second one is a regular Cartesian mesh of receptors, located in the wind downstream that will show us the pollution level where we do not have samplers. So once we have checked with the first type of receptors that the software is doing right by comparing measured values with the simulated ones, we can rely on the simulated values that are given by the second type of receptors.

Table 6: Meteorological calculated values.

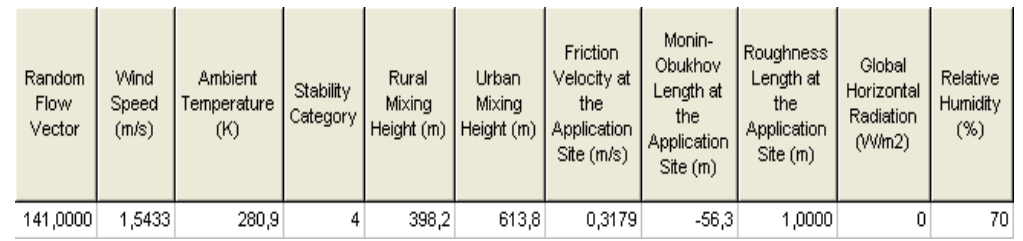


The emission rate by area unit is the parameter that will be modified, tuned, until we get the adjustment of the simulation to the field data. Once all the parameters are introduced we obtain results shown in Figure 14 and Table 7, where we are showing respectively concentration isosurfaces and the values obtained by the software simulation in the sampled points. We can clearly see how the dust is dispersed in the wind direction in an opening cone shape (figure 15). If we proceed in the same way with the second blasting measurements we obtain analogue outputs shown in Figures 16,17 and Table 8. This time the source has to be double, as the dock is made by two different areas (one point source and another polygonal source).

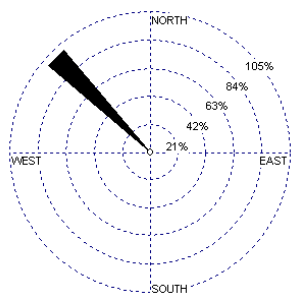

Figure 13: Wind rose.

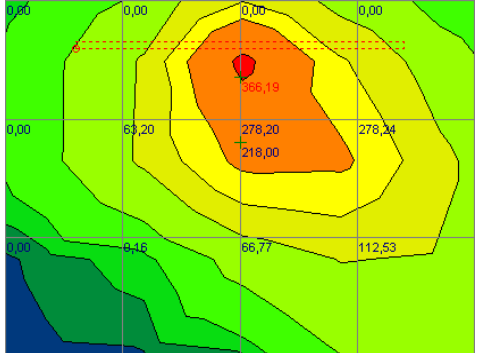

Figure 14.

Table 7.

\begin{tabular}{|c|c|}
\hline \multicolumn{2}{|c|}{ Dust concentration } \\
\hline Field measures & ISCT3 Simulation \\
\hline $359 \mu \mathrm{g} / \mathrm{m}^{3}$ & $366 \mu \mathrm{g} / \mathrm{m}^{3}$ \\
\hline $220 \mu \mathrm{g} / \mathrm{m}^{3}$ & $218 \mu \mathrm{g} / \mathrm{m}^{3}$ \\
\hline
\end{tabular}

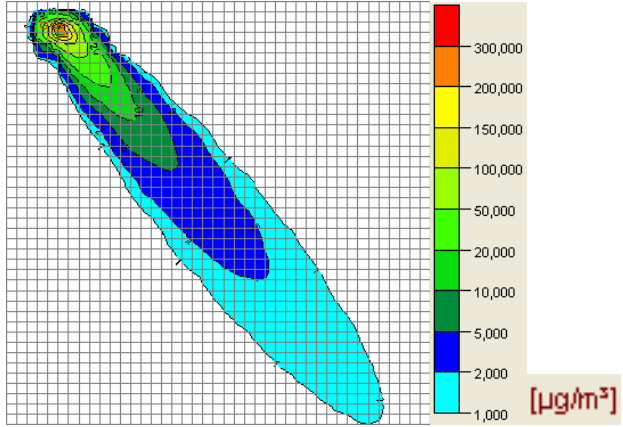

Figure 15.

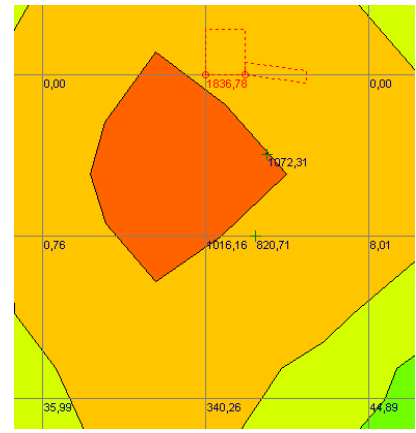

Figure 16. 
Table 8.

\begin{tabular}{|c|c|}
\hline \multicolumn{2}{|c|}{ Dust concentration } \\
\hline Field measures & ISCT3 Simulation \\
\hline $1069 \mu \mathrm{g} / \mathrm{m}^{3}$ & $1072 \mu \mathrm{g} / \mathrm{m}^{3}$ \\
\hline $829 \mu \mathrm{g} / \mathrm{m}^{3}$ & $820 \mu \mathrm{g} / \mathrm{m}^{3}$ \\
\hline
\end{tabular}

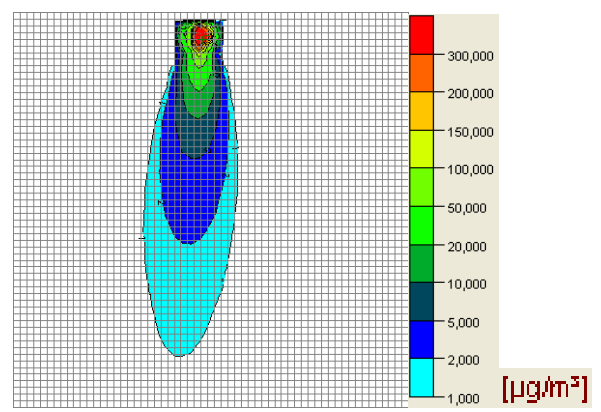

Figure 17.

\subsection{Limestone quarry blasting}

Following the methodology described in the previous case the results for the first group of samples are shown in Table 9 and in figure 18. Figure 19 shows the cone dispersion (concentration) of the particulated material as was obtained from the simulation.

Table 9.

\begin{tabular}{|c|c|}
\hline \multicolumn{2}{|c|}{ Dust concentration } \\
\hline Field measures & ISCT3 Simulation \\
\hline $177 \mu \mathrm{g} / \mathrm{m}^{3}$ & $177 \mu \mathrm{g} / \mathrm{m}^{3}$ \\
\hline
\end{tabular}

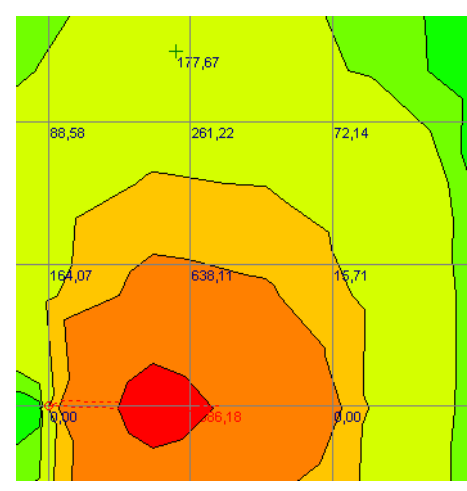

Figure 18.

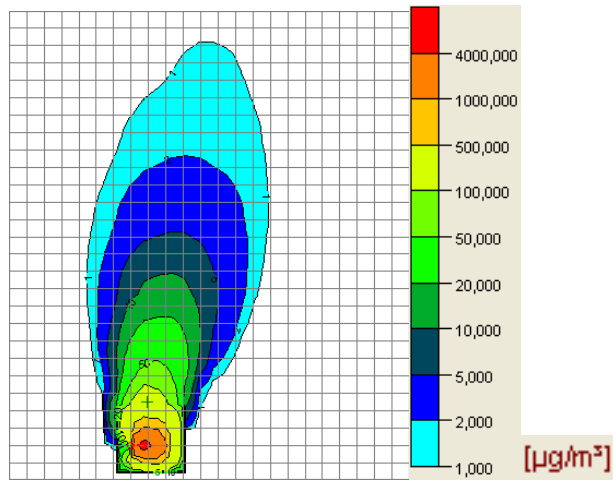

Figure 19. 
Proceeding again in the same way the second group of blasts calculations are shown in Table 10, Figure 20 and Figure 21.

Table 10 .

\begin{tabular}{|c|c|}
\hline \multicolumn{2}{|c|}{ Dust concentration } \\
\hline Field measures & ISCT3 Simulation \\
\hline $733 \mu \mathrm{g} / \mathrm{m}^{3}$ & $825 \mu \mathrm{g} / \mathrm{m}^{3}$ \\
\hline $406 \mu \mathrm{g} / \mathrm{m}^{3}$ & $400 \mu \mathrm{g} / \mathrm{m}^{3}$ \\
\hline
\end{tabular}

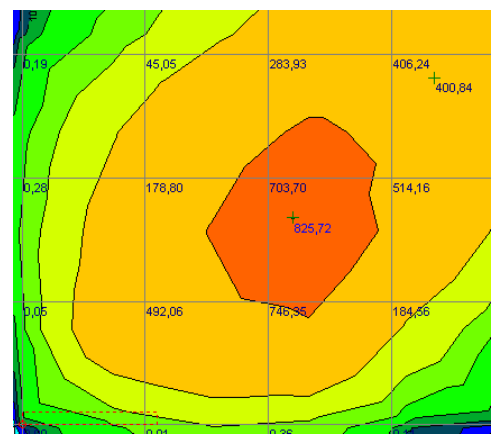

Figure 20 .

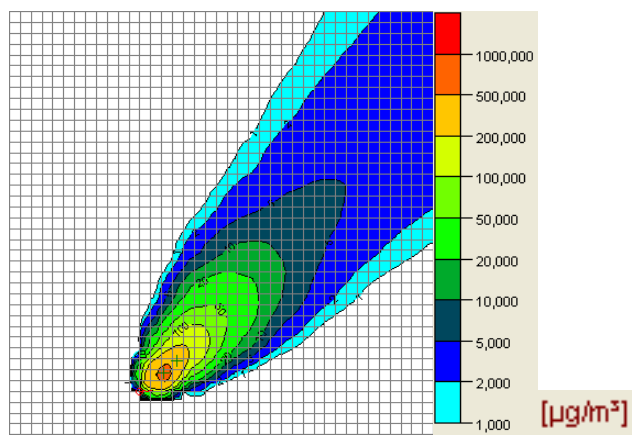

Figure 21.

\section{Conclusions}

In mining and civil works blasts is possible to establish prediction models that simulate with enough accuracy and simplicity the behaviour of the emission and propagation of the particulated material using easy-to-use software as ISC3, [8] and [9]. This is done through the adjustment of the software using a simple measurement campaign deploying dust collectors and meteorological sensors. In case of complex blasting geometries or highly irregular terrain is necessary to use other modelization tools as numerical codes (CFD).

\section{References}

[1] J. Toraño et al. (2003) Oviedo University-Ministry for Development Contract FOM 1540/2002 (within the Priority Action Framework "New Technologies and Constructive Systems", of the Sectorial Area "Building and Cultural Heritage Conservation” National R\&D\&I Plan 2000-2003).

[2] J. Toraño, R. Rodríguez, J.M. Rivas, A. Pelegry (2004) Diminishing of the dust quantity during the management of granular material in an underground space. XII International Conference on Modelling Monitoring and management of Air Pollution (Air Pollution 2004).

[3] J. Toraño et al. (2004) Oviedo University, Carbonar Company and FICYT (R\&D Foundation) Contract IE 03-86 
[4] Several studies at "Instituto Nacional de Silicosis" (National Institute for Silicosis), Spain.

[5] Annual Report of the International Agency for Cancer Research. 1997.

[6] Ferrán Ballester (2003): Estudio multicéntrico español sobre la relación entre contaminación atmosférica y mortalidad. EMECAM-EMECAS. Medicina Clínica. Madrid.

[7] Environmental Contamination and Global Climate Change. The future for our children. Fourth Ministerial Conference on Environment and Health, WHO. Budapest, 2004.

[8] ISCST3 and AERMOD of software ISC-AERMOD View 4.6.2b from Lakes Environmental Software.

[9] ISCST3, (1999): U.S. EPA, 1999. Addendum - Users Guide for the Industrial Source Complex (ISC3) Dispersion Models, Volume 1. Office of Air Quality Planning and Standards, Research Triangle Park, NC. RAMMET, U.S. EPA - 454 / B-96-001 (Revised June 1999) 